International Research Journal of Management, IT \& Social Sciences
Available online at https://sloap.org/journals/index.php/irjmis/
Vol. 8 No. 3, May 2021, pages: 228-235
ISSN: 2395-7492
https://doi.org/10.21744/irjmis.v8n3.1487

\title{
Social change and marriage structure in Nigeria
}

May Omogho Esiri ${ }^{\text {a }}$

Article history:

Submitted: 27 January 2021

Revised: 9 March 2021

Accepted: 18 April 2021

\section{Keywords:}

marriage structure, modernization, polygyny, social change, universal phenomenon.

\begin{abstract}
Marriage as a social institution has undergone changes in structure in contemporary Nigeria. Whether in simple or complex societies, social change is a universal phenomenon. In most cultural groups in indigenous Nigeria, marriage is usually an arrangement between two individuals. As a result there is pressure on the spouses to make the marriage a success bearing in mind the fact that any problem will usually affect both families and strain the otherwise cordial relationship between them. Again, polygyny commonly known as polygamy is the most practiced marriage system. However, the marriage structure in Nigeria today has not been the same. It is found in the name of modernization or civilization that a girl and a boy may decide to marry away from their parents' place of residence and without their consent. Monogamous marriage is now increasingly encouraged and practiced. The paper thus examines the extent of social change in the Nigerian marriage structure.
\end{abstract}

International research journal of management, IT and social sciences (C) 2021. This is an open access article under the CC BY-NC-ND license (https://creativecommons.org/licenses/by-nc-nd/4.0/).

\section{Corresponding author:}

Esiri, M. O.

Department of Sociology and Psychology, Delta State University, Abraka

Email address: esirimay@yahoo.com 


\section{Introduction}

Social change occurs in all societies because it is a universal phenomenon. It is said that the only thing that is constant in life is change. The rates or levels of change in every society need not be the same because social change does not occur with equal rapidity in all societies. Also some societies are more receptive to change than others. Social change takes place all the time. The processes of social change may be imperceptible, and may not be dramatic but to the extent that some human activities go on, some changes are being effected. This implies that social change may be interpersonal and may not involve the whole of all society or all institutions. Udoh (1986) defined social changes as an alteration in the social order of society. Igbo (2003) described social changes as the alterations in the pattern of culture, social structure and social behavior over time. It refers to the modifications that occur within social attitudes, beliefs, values, and patterns of relationships and behavior (Igbo 2003; Williams, 2009; Waldron et al., 1996). Again, Ferrante (2006), defined social change as any significant alteration, modification or transformation in the organization and operation of social life.

Furthermore, Odetola \& Ademola (1985) points out that, "change has become so universal that it has been contended that most human societies today are converging towards a common technological age. Technology is spreading so rapidly that we are likely to find similar values in distant parts of the world. Before the colonial conquest which began in the $19^{\text {th }}$ century, one of the fundamental characteristics of traditional society in Nigeria was the polygamous marriage (marriage of one man to two or more wives).

However, suddenly colonization brought Nigerians into close social contact with the Western Group/Society; their beliefs, customs and traditions. This contact introduced the monogamous marriage to the Nigerian society through the Christian religion which preaches 'one man, one wife'. Marriage, as identified by Otite \& Ogionwo (2006) is part of our daily lives and it is a universal concept that does not have a generally acceptable definition. Various authors have attempted to define it as they deemed fit. Leach (1961) defined marriage as a process whereby a person leaves his/her household to be joined with their spouse in order to raise their own family. Also, Horton (1984) defined marriage as the approved social pattern whereby two or more persons establish a family. Since the advent of western colonization, processes of urbanization, modernization as well as globalization have enhanced changes in the traditional Nigerian marriage structure which though generally similar, varied in some ways from one ethnic group to another. For example, though polygamous marriage was common, concubinage which was closely associated with the marriage culture was not practiced by all ethnic groups. Marriage for the African people is the basis of existence and the institution of marriage is beneficial to all and to society (Onwuejeogwu, 1994; Tapio et al., 2011; Chimbiri, 2007). This is especially because it is the fundamental building block of society. It is important to note here that while the concept of marriage remains the same across the globe, the process of solemnizing it differs extensively.

\section{Importance of Marriage}

Marriage is a very important aspect of an individual's life. Some importance of marriage has been identified as follows:

- It actually makes an incomplete human being complete. It makes him/her a grown up and gives him/her responsibilities, which are to feed and clothe the wife or to assist the husband or otherwise.

- Marriage is supposed to take the persons involved out of their hectic life style and place them in a path to follow in life and a shoulder to lean on.

- Marriage also prevents/reduces sexual immoral act.

- Again, noteworthy is the fact that humans are essentially social animals. They fear loneliness and cannot live or grow their full potentials in isolation. They have a genetically driven need to reach out to other people and marriage fulfils this need.

- In addition, human beings know subconsciously that if they remain at the tender mercies of the natural world they will not be able to survive for long. They also think that the best way to eliminate that insecurity and loneliness is to establish and form a bond with an individual of opposite gender.

- Marriage is the only institution that allows two people to establish a very strong and enduring relationship that is fully backed by the law and society as a whole. This is the reason why the institution of marriage has been around for so long.

- Living Together: In a marriage the individuals involved, come together to set up a home of their own. They live under the same roof and sleep on the same bed. This ensures that the two parents no longer feel lonely and

Esiri, M. O. (2021). Social change and marriage structure in Nigeria. International Research Journal of Management, IT and Social Sciences, 8(3), 228-235. https://doi.org/10.21744/irjmis.v8n3.1487 
regularly have access to each other as close companions as often possible. They can speak to each other anytime they want and generally benefit from each other's physical presence.

- Functional Division of Labour: Marriage creates functional division of labour in all of life's activities for the couple. The wife usually takes care of house hold work such as laundry and cooking food while the husband goes out to work everyday to provide for the family needs. This makes things easier for both of them and they develop a specialization in the area of work, concentrating fully on the individual's responsibilities.

- Financial Security: When two people get married, their lives intertwine in more ways than one. They bring together savings and assets they accumulated in the past. This combined wealth increases the purchasing power of both spouses and they can afford to collect many luxuries for the home to make their life comfortable. If both the spouses have jobs then their salaries jointly add up to a tidy sum and they can now afford many assets, both movable and immovable which most likely, they could not afford earlier.

- Emotional Support: The biggest benefit marriage offers to the partners is emotional support. The spouses stay together and lead a closely knitted life. They share their personal secrets with each other and discuss all life's big and small events. They also go to social functions together as one unit. When a partner is depressed or life takes a sudden turn for the worse, he/she is provided support by way of soothing words and encouragement by the spouse.

- Rearing Children: To have children and begin a family, there really is no better option than getting married. This is because the task of raising children is easier. They are able to establish a safe and secure nest in which the children can be reared to grow up into healthy adults. While the father ensures discipline, general guidance, and physical security for the children, the mother offers them soft emotions such as tenderness, intimacy and affection.

- Social and Legal Recognition: Marriage unlike live-in relationships is an institution that has the full backing of the society and law. A married man and wife have a certain social status and respect that is denied people who have never been married. Marriage is also recognized by the law and has legal validity. The rights and duties of the married couple are well defined and enforceable in a court of law. If partners want to split, there is a particular procedure that has to be followed with respect to not only uniting the relationship but also for matters related to division of assets and liabilities, child custody, and maintenance to be payable to wife.

\section{Traditional Marriage Structure in Nigeria}

Polygynous Marriage was the common indigenous system of marriage in the Nigerian traditional society. Polygyny system of marriage in which a man marries more than one wife is what is popularly known as polygamy (Ogionwo \& Otite, 2000). An individual, who marries many wives, performs as many marriage ceremonies. Each ceremony and acquisition of an additional wife creates a new network of relationship and new opportunities for children. Such a man is expected to obtain these wives form different families and towns. In particular, some traditional rulers in Africa have been known to use this as a means of creating trusted and loyal relationships and keeping together the kingdom (Otite \& Ogionwo, 2006; Sherkat et al., 2011; Pahl, 1995). A man's 'wealth' of wives was also relevant and reckoned with in giving/receiving chieftaincy tittles. There is no doubt therefore that the value attached to a large number of wives and children in terms of prestige, reputation labour force, defense and leadership helped to entrench the practice of polygyny. Despite the practice of polygyny, marriage spouses were expected to live together in peaceful co-existence and co-operation with one another and with relatives in the maintenance of the household. Within the Nigerian context there was some degree of pressure on a matured individual to get married in most ethnic groups. Therefore, bachelorhood and in particular spinsterhood were social abnormalities. A man or woman who refused to get married was considered as socially not responsible. So also, a marriage that failed to produce children was seen as abnormal and treated with disregard and disrespect.

There were four important prerequisites of marriage in the Nigerian traditional society: the approval and involvement of the families of the spouses, circumcision of the bride, bride wealth (or bride price) payment, and a religious factor (Odetola, 1985; Onwuejeogwu, 1994; Wilcox \& Wolfinger, 2007; Brown, 2004).

- In the past, parents decided the marriage of their children and it was the social responsibility of relatives to make sure that eligible individuals entered into approved marriages. Also there were rules of incest which prevented certain relatives from having sexual intercourse and from marrying each other. For example, marriage between cousins was not allowed among the Urhobos in Nigeria. 
- The second essential requirement of bride wealth or bride price must be made to the girl and her parents before the contract of marriage is completed. Both bride wealth and/or dowry varies from one ethnic group to another or from one family to another. However, the bride wealth is not paid to make the woman an economic commodity. Rather, it is a calculated payment with legal and social implications made to establish the marriage (Esenstadt, 1973; Nathanson, 1980; Allendorf \& Ghimire, 2013). Acceptance of the payment by the parents, is an indication that they approve of the new relationship. Bride wealth can be made in various forms. For example it could be paid in cattle as among the Fulani's in Nigeria or cowries or other forms of money as practiced among the Urhobos, Igbos and Yoruba's.

- The third important requirement of marriage in indigenous Nigeria, is that of religious activity through African Traditional Religion. Ancestors of the spouses are involved through libation and prayers to participate in the marriage ceremony. They are to bless and protect the union created by the two spouses and their families. The practice is to pour some quality of the locally brewed gin as libation while prayers are addressed and appeals are made to the ancestors who are seen to play vital roles in marriage. These dead ancestors are believed to be also living, unseen, yet around with supernatural powers to sanction and to protect the couple or punish them through some illness if any of the spouses contravened the rules of marriage, especially as it concerns sex (Otite \& Ogionwo, 1994). Mbiti (1984), observed that, marriage for the African is the point where all members of a given community meet the departed, the living, and those yet to be born. All the dimensions of time meet there and the whole drama of history is repeated and revitalized (Mbiti, 1984).

- The fourth prerequisite in the marriage pattern is that, the girl must be circumcised if the parents have not done so before. This is most practiced among the Urhobos and the Ukwuanis of Delta State (Okwechise, 2012). The Igbos of Southern Nigeria are not known to practice this. At this point, it is important to note that a woman in indigenous Nigeria, was expected to remain a virgin before marriage, and after marriage, she confirms her virginity to her husband's family and her family by the evidence of the blood stained bed spread through her first intercourse with her husband.

\section{Forms of Marriage}

Forms of marriage identified by some sociologists (Anyagbolu, 1977; Onwejeogwu, 1994; Otite \& Ogionwo, 2006) include Girl/Woman marriage, widow marriage, charity/gift marriage (among the Fulanis, Kanuris and Urhobos); Cousin Marriage (among the Kanuris), betrothal, contract and 'forced' marriage (among the Fulanis) as identified by Anyagbolu (1977) and Onwejeogwu (1994). Marriages were contracted to last till death though divorce occurred in rare cases, particularly in cases of witchcraft accusations by a spouse, if confirmed (Anyagbolu, 1977; Chidi 1998, Otite \& Ogionwo, 1994, Georgina, 2012).

- Marriage by Betrothal Betrothal marriage is carried out by the parents of those to get married. The choice of spouse, may be done even before the intending couple are born. In this type of marriage, the parents of a household where there is a boy goes to another household where there is an expectant mother and puts in an application for the event at her delivery, the child is a girl. On the other hand, the parents may go to the household where a girl is present and ask for a favour (that is, a wife) and if their request is accepted, the two parties fix the date for the marriage ceremonies. The bride wealth is then paid by the prospective husband or by an elder from his family in his absence. When the marriage ceremonies have been completed, a day will be fixed for leading the bride to the husband's house.

- Courtship Marriage: This type of marriage results from the failure of the betrothal marriage. The courtship marriage involves a period of time. It is usually initiated by the suitor who goes to the relatives. Some ceremony of breaking and eating kola nuts as well as drinking palm wine, libations, and prayers offered to ancestors take place to indicate marital relationship. The popular practice of splitting kolanut marks a ritual exchange and union between the contracting families to the marriage. Again during the period of courtship the suitor is expected to at least give gifts and services to the parents of the wife. Gradually, the girl is allowed to visit the man occasionally. The number of months or years for the courtship is not fixed. It depends on the suitor and sometimes on the family of the girl. After several visits a day is fixed for the payment of bride wealth after which an arrangement should be made to escort the wife to the husband's place.

- Forced Marriage: In the past, some parents forced their children especially daughters into marriage. Parents did it in appreciation for some or 'a good turn' (as it is commonly said, 'one good turn deserves another') rendered to them or their children. Sometimes also, to maintain an already established close relationship, a

Esiri, M. O. (2021). Social change and marriage structure in Nigeria. International Research Journal of Management, IT and Social Sciences, 8(3), 228-235. https://doi.org/10.21744/irjmis.v8n3.1487 
daughter or a son is forced into marriage. In most cases, the spouses end up marrying a man or woman that is against their will. Again, a family who needs money or help and could not solve their immediate problem, could give out their daughter to a man for marriage. This man in return would give in exchange money or help to the parents of the girl. Furthermore, a girl who is seen to be in immoral conduct could be forced into marriage in order to eradicate from her the idea of irresponsibility. However, forceful marriage is not rampant. All marital rites in this type of marriage have to be performed within a short period.

- Widow Marriage/Levirate: The custom of inheriting the wife of a deceased brother is referred to as widow marriage/levirate. A Brother in this case does not only apply to someone of same mother, but any other close relative even if the widow had children for their brother. The family of the deceased man meets after performing the burial rites to decide who should inherit the widow. After the decision, traditional rites are performed according to the custom of land to dissolve the old union between the window and the deceased husband, and to establish the new union between her new husbands. The man who inherits the wife does not inherit the children but performs all duties of a father to children. The idea of marrying a widow is to help the woman to care for the children of the deceased husband. If the woman refuses to marry her husband's son or the brother then certain rites would be performed and she will be allowed to marry outside her husband's family. In this case her new husband would pay back her bride wealth to her deceased husband's family. On the other hand, if the window does not want to remarry, she may be allowed to remain in her husband's house and take care of her children.

- The first three prerequisite of the approval and involvement of the families of spouses parental approval, bride wealth (or bride price) payment, and a religious factor in the process of marriage are what give legality to the marriage and set up various legitimate reciprocal rights and obligations. Mair (1965) clearly epitomized marriage as the arrangement of the social structure which therefore creates a new relationship and new reciprocal rites between spouses and between their kins to establish what will be the right and status for the children when they are born.

\section{Marriage Structure in Contemporary Nigeria}

Today in Nigeria, foreign Christian churches, do not permit their adherents to marry more than one wife. In fact they forbid them and help to propagate the monogamous marriage system (that is, a man is expected to marry only one wife and may be allowed to marry another wife only after he had divorced the first one). In fact the churches forbid their members from practicing polygyny (polygamy), the indigenous marriage culture and social pattern. While monogamy leads to the formation of a social unit of one man, one wife and their children (that is, nuclear family), polygamy leads to the formation of one man, two or more wives and their children (that is, the extended family). There is no doubt that there is a gradual decline of polygamous marriage (Beatie, 1964). This has given rise to what Beatie (1964) called a decision, signifying the conflict which Africans face because they want to maintain their tradition and at the same time practice the new innovations.

Also, with the combined processes of modernization, civilization and globalization, high technological development, their unwavering and steady influence on the Nigerian population, particularly the youths, girls and boys decide whom to marry even if it means marriage without parental consent. African elites and Christian missionaries were major actors in the process of changing marriage in Africa from a kinsmen affair to an individual affair. Therefore, families may not be involved as they were in the past, and couples no longer have the checks and balances of the two families that ought to have been established in a new social relationship. So the marriage institution that was seen to be sacred and held in high esteem is fast becoming a harem or haven of divorce and separation, or 'empty shell' marriage. Customary or indigenous marriage was very enduring, obligations were continuous for as long as the marriage existed and divorce either did not exist in some ethnic groups or were quite rare. Again, Otite et al. (2006) observed that "there is a drift in bride wealth payment in recent times. the amount of bride wealth paid now depends on both the quality of the girl in terms of virginity and morals (sometimes but not often nowadays), and principally on the wishes of the girl's parents" (Otite et al., 2006). Therefore, bride wealth in Nigeria now varies a great deal and some parents give their daughters in marriage without bride wealth (that is, gift marriage) Furthermore, Lloyd (1974), noted that in traditional Africa, in choosing a wife, or husband, emphasis was placed on, not only the wealth and character of the individual but on that of all members of her descent group. Sofolowa (2003) noted that in most traditional African societies, it may be considered that it is only after the acceptance of the bride wealth payment, that the man has right to the woman as his wife. Before the payment, the woman must not engage in sexual intercourse 
with the man. But nowadays as Sofoluwa (2003) further states, premarital pregnancy is seen as a means of ensuring fertility. Apart from the African traditional religion, other foreign religions are now involved in the marriage pattern. Such religions include the Catholic, Protestant, Pentecostal, Seraphim and Cherubim, or any other form of church, or Islam. All of these invoke some supernatural powers to bless the marriage. Also noteworthy is the gradual elimination of female circumcision as a basic prerequisite for marriage.

\section{Theory}

The theory used for this paper is the cultural diffusionist theory. It was first conceptualized by Kroeber (1994). Cultural diffusion is the spread of cultural items such as ideas, styles, religious, technologies, languages, and others, between individuals whether within a single culture or from one culture to another. It is distinct from the diffusion of innovations within a single culture. Inter-cultural diffusion can happen in many ways. Migrating population will carry along with them their culture, values and so also, transcultural visitors, such as merchants, explorers, colonizers soldiers, diplomats, slave and hired artisans (Mode, 1995). Among literate societies, diffusion can happen through letters or books (and in modern times through, other media as well, such as the internet). There are three categories of diffusion mechanism:

- Direct Diffusion: Direct diffusion is when two cultures are very close to each other, resulting in intermarriage, trade and even warfare. An example of direct diffusion is between the United States and Canada where the people living on the borders of these two countries engage in hockey, which started in Canada, and baseball, which is popular in American culture.

- Forced Diffusion: This occurs when one culture subjugates (conquers or enslaves) another culture and forces its own customs on the conquered people. An example would be the forced 'Christianization' of the indigenous populations of the Americas by the Spanish, French, English and Portuguese, or the forced Islamization of West Africa people.

- Indirect Diffusion: Indirect diffusion happens when traits are passed from one culture, without the first and final cultures ever being in direct contact. An example could be the presence of Mexican food in Canada since a large territory (the United States) lies in between. Diffussionism, also denotes the spread of cultural elements either singly or combination, from one society to another through the processes of borrowing, suggestion or migration. The cultures concerned must be distinct but there must be some contact. Through that process, the distinct cultures eventually come to have similarities in some of their cultural traits. An important Kernel of diffusionism is the point that no human group exist by itself without contact with an outside group. Therefore, the origin of certain cultural elements of any group can be traced to some other cultures. In extreme cases, diffusionists are of the view that the cultural traits of known groups have common source (Modo, 1995).

This is especially the position of the British school of diffusionism which is of view that no society has developed or can develop in isolation, without the influence of other cultures, often a neighboring society. The British school holds Egypts as the cultural center of the world. However, German school of diffusionism contends that Egypt was not the only source of word culture and that cultural elements derive from a multiplicity of centers. It was possible for people in isolated societies not having communication and transportation linkages to invent things and thereby develop their cultural element in isolation. These cultures however, later spread to other societies following the development of communication facilities and subsequent contacts. Modifications or even loss of the original elements might have occurred as two or more cultures made contacts (Otite \& Ogionwo, 2006).

Social change in Nigerian marriage structure can be linked to the diffusionist theory. In a nutshell the changes are as a result of British Colonization intermarriage between the visitors or between ethnic groups, according to diffusionist theorists like Otite \& Ogionwo (2006), the diffusion of cultural traits rest on the process of selection or rejection by the cultural group.

\section{Conclusion}

There is no doubt that there are some new trends in marriage structure in Nigeria today. There is evident increase in monogamous marriages as compared to polygamous marriages. Also evident in this paper is that the new patterns of

Esiri, M. O. (2021). Social change and marriage structure in Nigeria. International Research Journal of Management, IT and Social Sciences, 8(3), 228-235. https://doi.org/10.21744/irjmis.v8n3.1487 
marriage in contemporary Nigeria is enhancing and resulting in increasing divorce cases. It is important to note that divorce was very rare (except for cases of witchcraft). Cases of adultery were settled through cleansing rites.

\section{Recommendation}

The paper suggests that since monogamy is gradually being widely accepted by Nigerians, it should be retained. Also, noteworthy is the fact that the Christian marriage accommodates often times, the traditional marriage. Again of importance is the argument that monogamy is more economical in terms of family size and as a result families and households are more manageable and more convenient. However, because of the high divorce rate that accompanies the contemporary marriage structure, the paper recommends well trained marriage counselors to work in counseling centers that should be established (at least two) in every local government headquarter.

\section{Conflict of interest statement}

The author declared that he has no competing interests.

\section{Statement of authorship}

The author has a responsibility for the conception and design of the study. The author has approved the final article.

Acknowledgments

I am grateful to two anonymous reviewers for their valuable comments on the earlier version of this paper. 


\section{References}

Allendorf, K., \& Ghimire, D. J. (2013). Determinants of marital quality in an arranged marriage society. Social science research, 42(1), 59-70. https://doi.org/10.1016/j.ssresearch.2012.09.002

Beatie, J. (1964). Other Cultures. London: Cohen and west.

Brown, S. L. (2004). Moving from cohabitation to marriage: Effects on relationship quality. Social Science Research, 33(1), 1-19. https://doi.org/10.1016/S0049-089X(03)00036-X

Chidi I. E (1998). Utagba uno history and culture of Ukwuani Speaking people. Lagos: Jone Publications.

Chimbiri, A. M. (2007). The condom is an 'intruder'in marriage: evidence from rural Malawi. Social science \& medicine, 64(5), 1102-1115. https://doi.org/10.1016/j.socscimed.2006.10.012

Fadipe, S. O and Alubo, A. (2004). African traditional and its practices. Ibadan: University press.

Ferrante, J. (2006). Sociology. Belmont United States of America: Thompson Higher Education.

Horton P. B. and Hunt C. L. (1984). Sociology. Singapore: McGraw Hill Book Co. $6^{\text {th }}$ Ed.

Lloyd,P. C. (1972). African social change: changing traditional societies in Nigeria world. Journal of African History $\mathrm{X}(4)$.

Mair, (1971): Marriage. London: Penguin.

Mbiti, J.S. (1969). African religion and philosophy. London: Heinemann Press.

Modo, W. O. (1995). A Handbook on Theories and methods in anthropology. Akwa Ibom State: Dorand Publishers.

Nathanson, C. A. (1980). Social roles and health status among women: The significance of employment. Social Science \& Medicine. Part A: Medical Psychology \& Medical Sociology, 14(6), 463-471. https://doi.org/10.1016/S02717123(80)80050-2

Okwechise, G. (2012). Marrying well: Marriage, status and social change in Utagba-uno Marriage Structure. Lagos: Delgard Ventures.

Onwuejeogwu, M. A (1994). The social anthropology of Africa: An introduction to parents choice arrangements: divorce was harmless operation. Ibadan: Heinemann Educational Books (Nig.) Plc.

Otite, O. and Ogionwo, W (2006). An Introduction to sociological studies.(2 ${ }^{\text {nd }}$ ed.) Ibadan: Heinemann Educational Books (Nigeria) Plc.

Pahl, J. (1995). His money, her money: Recent research on financial organisation in marriage. Journal of economic psychology, 16(3), 361-376. https://doi.org/10.1016/0167-4870(95)00015-G

Sherkat, D. E., Powell-Williams, M., Maddox, G., \& De Vries, K. M. (2011). Religion, politics, and support for samesex marriage in the United States, 1988-2008. Social Science Research, 40(1), 167-180. https://doi.org/10.1016/j.ssresearch.2010.08.009

Tapio, P., Paloniemi, R., Varho, V., \& Vinnari, M. (2011). The unholy marriage? Integrating qualitative and quantitative information in Delphi processes. Technological Forecasting and Social Change, 78(9), 1616-1628. https://doi.org/10.1016/j.techfore.2011.03.016

Waldron, I., Hughes, M. E., \& Brooks, T. L. (1996). Marriage protection and marriage selection-prospective evidence for reciprocal effects of marital status and health. Social science \& medicine, 43(1), 113-123. https://doi.org/10.1016/0277-9536(95)00347-9

Wilcox, W. B., \& Wolfinger, N. H. (2007). Then comes marriage? Religion, race, and marriage in urban America. Social Science Research, 36(2), 569-589. https://doi.org/10.1016/j.ssresearch.2006.02.005

Williams, N. (2009). Education, gender, and migration in the context of social change. Social science research, 38(4), 883-896. https://doi.org/10.1016/j.ssresearch.2009.04.005 